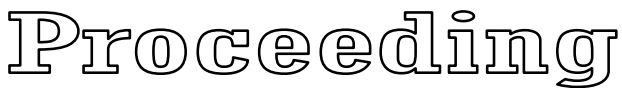 \\ The $1^{\text {st }}$ International Seminar on Chemical Education 2015 \\ September, $30^{\text {th }} 2015$
}

\section{Utilization Effectiveness of Chemistry Instructional Media to improve Self Regulated Learning and Learning Outcomes of High School Students}

\author{
Yogo Dwi Prasetyo, ${ }^{1, *}$, Irwanto ${ }^{2}$ \\ ${ }^{1}$ Science Education Department,Postgraduate Program, Yogyakarta State University, \\ Jl. Colombo 1 Yogyakarta *email: prastyogo@gmail.com \\ ${ }^{2}$ Environmental Chemistry Teacher, Tiga Maret Senior High School Yogyakarta
}

\begin{abstract}
The aim of the study is to determine the different improvement of self regulated learning and learning outcomes between students using android-based chemistry instructional media and and students using conventional learning. This research used quasy experiment with nonequivalent control group design. The subjects of this research were students of SMA N 1 Banguntapan grade XI, consisted of one experimental class and one control class. The data collecting technique was done by using questionnaire and test. The data analysis technique was done by MANOVA. The result showed that there is significant differences in the improvement of self regulated learning and learning outcome between students using android-based chemistry instructional media and and students using conventional learning.. The average learning outcome of experimental class is 84.75 and control class is 77.42.
\end{abstract}

Keywords: Chemistry Instructional Media, Self Regulated Learning, Learning Outcomes

\section{Introduction}

Currently the developments of information and communication technology showed increased very rapidly. This developments directly affect the pattern of public interaction. The education sector was not immune from the influence of the development of ICT. The development of ICT in education can be seen in a variety of systems and learning resources, such as e-learning or use of instructional media.

The use of ICT-based instructional media has a very good role in improving the academic performance of students. ICT-based instructional media can be used to improve the learning outcomes of students (Chuang \& Chen, 2007 and Matsuo et al, 2008). The use of instructional media also helps students to study independently or self regulated (Song, Wong, \& Looi, 2012) and make the learners are challenged to solve problems through construction to think independently or self regulated (Jaladanki \& Bhattacharya, 2014).

The object of this research is chemistry learning of high school. According Sunyono et al. (2009), the subject matter of chemistry at high school contains many concepts which is quite difficult to understand by students, because it involves chemical reactions and calculations, and involves concepts that are abstract and microscopic. Results of studying chemistry in 


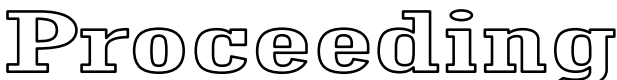

\section{The $1^{\text {st }}$ International Seminar on Chemical Education 2015 September, $30^{\text {th }} 2015$}

colloidal system also have not shown satisfactory results. This is shown in the results of mastery of the material on the national exam in 2013 only reached 76.14\% (Puspendik, 2013). For that we need a media that can be used to improve the chemistry learning outcomes of high school students.

This study aims to determine the effectiveness of the use of chemistry instructional media to improving learning outcomes and self regulated of students.

\section{Method}

This research is quasy experiment. The design used in this study is a non equivalent control group design. Instructional media used in this study is android-based chemistry instructional media. The subjects of this research were students of SMAN 1 Banguntapan XI MIA 2 grade as the control group and XI MIA 3 grade as the experiment group. The study design is shown in Table 1.

Table 1. Research Design

\begin{tabular}{cccc}
\hline Group & Pretest & Treatment & Posttest \\
\hline Experiment & O1 & $\mathrm{X} 1$ & O2 \\
Control & O3 & - & O4 \\
\hline
\end{tabular}

Description:

$\mathrm{X} 1$ = learning by using chemistry instructional media.

$\mathrm{O} 1=$ pretest before using chemistry learning media .

$\mathrm{O} 2$ = posttest after using chemical instructional media.

$\mathrm{O} 3=$ pretest before conventional learning.

$\mathrm{O} 4=$ posttest after conventional learning.

Data collected by questionnaires self regulated learning and achievement/outcome test. Data collection was done before learning and after learning takes place. Data obtained was calculated the gain score by the following equation (Hake, 1998).

$$
g=\frac{S_{f}-S_{i}}{100-S_{i}}
$$

$$
\text { Description: } \begin{aligned}
\mathrm{Sf} & =\text { final test } \\
\mathrm{Si} & =\text { initial test } \\
\mathrm{g} & =\text { gain }
\end{aligned}
$$




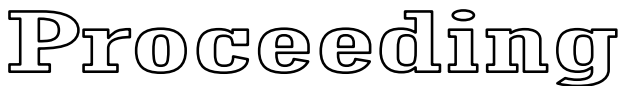

\section{The $1^{\text {st }}$ International Seminar on Chemical Education 2015 September, $30^{\text {th }} 2015$}

To determine the significance of chemistry learning outcome and self regulated learning of students, gain scores were analyzed by MANOVA. Test of MANOVA carried out after the test of normality and homogeneity requirements were met.

\section{Result and Discussion}

This study aim to determine the effectiveness of the use of chemical instructional media to improve learning outcomes and self regulated learnig from high school students. This study was conducted in SMAN 1 Banguntapan. The instrument used for data collection using questionnaires self regulated learning and chemistry achievement/outcome test. The instrument used was through the validation by experts and for instrument chemistry achievement/outcome test was also conducted empirical validation. Research instruments given to learners before learning takes place and after the study is completed. This was to determine the initial knowledge of learners and know the knowledge of students after participating in the learning process. The collected data were calculated the value of the gain. The average value of pretest and posttest study results is shown in Table 2.

Table 2. Average Value of Pretest and Posttest

\begin{tabular}{ccccccc}
\hline No & Group & Subject & $\begin{array}{c}\text { Pretest } \\
\text { Average }\end{array}$ & $\begin{array}{c}\text { Posttest } \\
\text { Average }\end{array}$ & Gain & Category \\
\hline 1. & Experiment & 32 & 36 & 84,75 & 0,757 & Tinggi \\
2. & Control & 31 & 37,16 & 77,42 & 0,632 & Sedang \\
\hline
\end{tabular}

Table 2 shows that the use of instructional media can improve learning outcomes are better than conventional learning. Improving of learning outcomes in learning that use chemistry instructional media are included in the high category (value gain of 0.757) whereas in conventional study only included in the medium category (value gain of 0.632 ).

Self regulated learning of students were also assessed before and after learning process. Average data of self regulated learning of students can be seen in Table 3.

Table 3. Average of Self Regulated Learning (initial and final)

\begin{tabular}{ccccccc}
\hline No & Group & Subject & $\begin{array}{c}\text { Initial } \\
\text { Average }\end{array}$ & $\begin{array}{c}\text { Final } \\
\text { Average }\end{array}$ & Gain & Category \\
\hline 1. & Experiment & 32 & 62,719 & 76,813 & 0,376 & Sedang \\
2. & Control & 31 & 64,548 & 74,489 & 0,279 & Rendah \\
\hline
\end{tabular}

Improvement of self regulated learning of students who use chemistry instructional media is also better than conventional learning. The average value of the gain in learning with chemistry instructional media are included in the medium category with gain value of 0.376 . Whereas in conventional teaching only in the low category with value gain of 0.279. 
The gain value then analyzed for normality and homogeneity. Normality test is done by calculating the Mahalonobis value. The calculation result can be seen in Table 4.

Table 4. Multivariate Analysis of Normality

\begin{tabular}{cccc}
\hline No & Group & $d_{i}^{2} \leq \chi_{\operatorname{mas}}^{2}(\%)$ & Conclusion \\
\hline 1. & Experiment & 40,625 & Normal \\
2. & Control & 45,161 & Normal \\
\hline
\end{tabular}

Based on the above data, it can be seen that the Mahalonobis value $\leq$ chi squared value, or $d_{i}^{2} \leq \chi_{p, 0.5}^{2}(1.38)$ are in the range of $40-60 \%$, it can be concluded that data are distributed multivariate normally.

Homogeneity test conducted by test Box M. The calculation result can be seen in Table 5 .

Table 5. Calculation Results of N-gain Homogeneity Test

\begin{tabular}{ccc}
\hline Effect & Significance & Conclusion \\
\hline Box's M & 0,884 & Homogenous \\
\hline
\end{tabular}

Box's M test results obtained significance value $(0,884)$ greater than 0.05 ( $p>0.05)$, so it can be concluded that the variance-covariance matrix is equal or homogeneous.

Results of normality and homogeneity tests are met then done MANOVA analyzed to determine the significance of differences in chemistry learning outcome and self regulated learning of students. MANOVA test results can be seen in Table 6 .

Table 6. Results of Manova Analysis

\begin{tabular}{ccc}
\hline Effect & Significance & Conclusion \\
\hline Hotelling's Trace & 0,000 & Ho ditolak \\
\hline
\end{tabular}

Manova analysis results in Table 10 shows that the significance value $(0,000)$ less than 0.05 ( $\mathrm{p}<0.05)$. Based on these results we can conclude that there are differences in chemistry learning outcome and self regulated learning students who use chemistry instructional media with the use of conventional learning. This is according to research conducted Chuang \& Chen (2007); Matsuo et al (2008); Mohamad \& Woollard (2012); Song, Wong, and Looi (2012); and Jaladanki and Bhattacharya (2014) that the learning media can be used to improve learning outcomes and self regulated learning of students. 


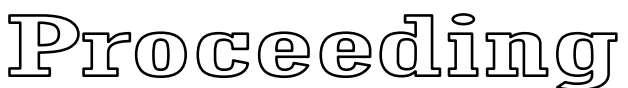 \\ The $1^{\text {st }}$ International Seminar on Chemical Education 2015 \\ September, $30^{\text {th }} 2015$}

\section{Conclusion}

Based on the results of this study can be concluded that there are significant differences in the improvement of learning outcomes and self regulated learning of students who use chemistry instructional media compared to conventional learning. Increase (gain) results of studying chemistry and self regulated learning of students who use chemistry instructional media are 0.757 and 0.376 , whereas in conventional learning are 0.632 and 0.279 . These results showed better improvement in learners who use the chemistry instructional media.

\section{References}

Chuang, T. Y., \& Chen, W. F. (2007). Effect of Digital Games on Children's Cognitive Achievement. Journal of Multimedia, 2 (5), 27-30.

Hake, R. R. (1998). Interactive-engagement versus traditional methods: A six-thousandstudent survey of mechanics test data for introductory physics courses. American Journal of Physics Research, 66 (1), 64-74.

Jaladanki, V. S., \& Bhattacharya, K. (2014). Exercising Autonomous Learning Approaches through Interactive Notebooks: A Qualitative Case Study. The Qualitative Report nova edu.

Matsuo, K., Barolli, L., Xhafa, F., Koyama, A., \& Durresi, A. (2008). New Function for Stimulating Learners' Motivation in a Web-Based e-Learning System. Journal of Distance Education Technologies, 6 (4), 34-49.

Mohamad, M., \& Woollard, J. (2012). Mobile Learning Via Mobile phone in Malaysian Secondary School : Seven Sign of Promises. The 8th International Scientific Conference, (p. 218). Bucharest.

Puspendik. (2013). Panduan Pemanfaatan Hasil Ujian Nasional Tahun Pelajaran 2012/2013 untuk Perbaikan Mutu Pendidikan. Jakarta: BSNP.

Song, Y., Wong, L.-H., \& Looi, C.-K. (2012). Fostering personalized learning in science inquiry supported by mobile technologies. Education Technology Research Development, 679-701.

Sunyono, I. W. W., Susanto, E., \& Suyadi, G. (2009). Identifikasi Masalah Kesulitan Dalam Pembelajaran Kimia SMA Kelas X di Profinsi Lampung. Jurnal Pendidikan MIPA, $10(2), 9-18$. 